\title{
EFEK ANTIHIPERGLIKEMIA INFUSA KANGKUNG DARAT (Ipomoea reptans Poir) TERHADAP KADAR GLUKOSA DARAH MENCIT JANTAN YANG DIINDUKSI STREPTOZOTOCIN
}

\author{
Farida Hayati ${ }^{1 *}$, Sitarina Widyarini ${ }^{2}$, Helminawati $^{1}$ \\ 1 Jurusan Farmasi Fakultas MIPA, Universitas Islam Indonesia, Yogyakarta \\ ${ }^{2}$ Fakultas Kedokteran Hewan, Universitas Gadjah Mada, Yogyakarta \\ "e-mail: farida_hayati@yahoo.com
}

\begin{abstract}
ABSTRAK
Penelitian ini dilakukan untuk mengetahui efek antihiperglikemia infusa kangkung darat (Ipomooa reptans P.) pada mencit Swiss jantan yang diinduksi streptozotocin (STZ) dengan parameter pengukuran kadar glukosa darah puasa (KGDP) dan berat badan. Sebanyak 30 ekor mencit Swiss jantan berat 20 - $30 \mathrm{~g}$ dibagi menjadi 6 kelompok ( $\mathrm{N}=5$ ), Kelompok I (kontrol normal) yang tidak diberi perlakuan. Kelompok II (kontrol negatif) diberi STZ dosis $40 \mathrm{mg} / \mathrm{kgbb}$ secara intra peritoneal selama 5 hari berturut-turut. Kelompok III (kontrol positif) diberi metformin $3,9 \mathrm{mg} / 20 \mathrm{gBB}$. Kelompok IV;V;VI diberi infusa kangkung darat dosis $44,64 \mathrm{mg} / 20 \mathrm{gBB} ; 89,28 \mathrm{mg} / 20 \mathrm{gBB}$; $178,56 \mathrm{mg} / 20 \mathrm{gBB}$. Kangkung darat diberikan secara p.o selama 7 hari berturut-turut yaitu pada hari ke-13 sampai hari ke-19 setelah pemberian STZ. Pengukuran KGDP pada hari ke-0 (sebelum pemberian STZ), hari ke-13, hari ke-20 dengan cara diambil darah secukupnya melalui ekor mencit Swiss jantan yang sudah dipuasakan sebelumnya dan diukur menggunakan glukotest . Data dianalisis dengan analysis of covarian (ANCOVA) dan analysis of varian (ANOVA) $(p=0,05)$. Hasil penelitian menunjukkan bahwa berat badan mencit diabetes rata-rata mengalami kenaikan dibandingkan kelompok kontrol normal sebesar $0,2 \mathrm{~g} /$ hari dan mencit Swiss jantan mengalami penurunan KGDP setelah diberikan infusa kangkung darat (lpomea reptans P.) dosis $44,64 \mathrm{mg} / 20 \mathrm{gBB} ; 89,28 \mathrm{mg} / 20 \mathrm{gBB} ; 178,56 \mathrm{mg} / 20 \mathrm{gBB}$ sebesar $21,27 \% ; 34,44 \% ; 31,18 \%$.
\end{abstract}

Kata kunci: kadar glukosa darah puasa (KGDP), kangkung darat (lpomea reptans Poir), metformin, streptozotocin (STZ)

\begin{abstract}
This research was conducted to determine the anti hyperglicemic effects of Ipomoea reptans $\mathrm{P}$ infussion in male Swiss mice induced streptozotocin (STZ) with the parameter measurement of fasting blood glucose levels (KGDP) and body weight. Thirty Swiss male mice (20 $30 \mathrm{~g}$ ) divided into 6 groups ( $\mathrm{N}=5$ ) which is called as normal control group, positive control group will be given metformin $3,9 \mathrm{mg} / 20 \mathrm{gBW}$, negative control group will be given STZ during five days at dose $40 \mathrm{mg} / \mathrm{kgBW}$ i.p and 3 treatment group will be given lpomoea reptans infusion at dose $44,64 \mathrm{mg} / 20 \mathrm{gBW}, 89,28 \mathrm{mg} / 20 \mathrm{gBW}, 178,56 \mathrm{mg} / 20 \mathrm{gBW}$ orally during 7 consecutive days from the 13 th day to $19^{\text {th }}$ day. Blood glucose levels and body weight Measurement will be done on day- 0 , day$13^{\text {th }}$, day- $20^{\text {th }}$. The data taken has been analyzed by ANOVA and ANCOVA tests and the result has been compared between groups I, II, III and control group.T here were no significant differencs $(p=0,05)$ between group I,II,III and control group. The result of this study showed that theaverage weight diabetic Swiss male mice compared with normal control weight increased 0.2 grams/day and the reduction in fasting blood glucose after being given lpomoea reptans at dose $44,64 \mathrm{mg} / 20 \mathrm{gBB} ; 89.28 \mathrm{mg} / 20 \mathrm{GBB} ; \mathrm{mg} / 20 \mathrm{gBB} 178.56$ consecutively $10.29 \% ; 29.66 \%,-4.42 \%$, $21.27 \%, 34.44 \%, 31.18 \%$.
\end{abstract}

Keywords: fasting blood glucose levels, lpomoea reptans Poir, metformin, streptozotocin 


\section{PENDAHULUAN}

Penelitian epidemiologi telah menunjukkan adanya kecenderungan peningkatan angka insiden dan prevalensi Dibetes Mellitus (DM) di berbagai penjuru dunia. Organisasi kesehatan dunia membuat perkiraan bahwa pada tahun 2000 jumlah pengidap diabetes di atas umur 20 tahun berjumlah 150 juta orang dan dalam kurun waktu 25 tahun kemudian yaitu pada tahun 2025, jumlah itu akan membengkak menjadi $\mathbf{3 0 0}$ juta orang. Sedangkan Indonesia akan menempati peringkat 5 sedunia dengan jumlah pasien sebanyak 12,4 juta orang pada tahun 2025 (Suyono et al., 2007).

Upaya pengatasan DM dapat ditangani dengan cara pengaturan pola makan dan olah raga teratur, penggunaan obat antidiabetes misalnya golongan sulfonil urea, biguanida, dan insulin. Alternatif pengobatan yang lain adalah pengobatan dengan bahan alam. Indonesia merupakan sumber mega biodiversity pertama di dunia dengan $\mathbf{3 0 . 0 0 0}$ spesies tanaman dan baru 940 spesies tanaman yang telah diketahui berkhasiat secara tradisional (Akib, 2006). Sasaran hasil riset nasional tahun $2025 \mathrm{di}$ bidang obat bahan alam adalah terproduksinya hasil eksplorasi sumber daya alam Indonesia oleh industri lokal (Agenda Riset Nasional 2010 - 2014). Hal itu memerlukan banyak studi eksplorasi obat bahan alam Indonesia.

Kangkung darat (Ipomoea reptans Poir) merupakan tanaman asli Indonesia yang secara tradisional biasa digunakan sebagai makanan sehari-hari dan dalam pengobatan diyakini secara empiris dapat menurunkan kadar glukosa darah. Hasil penelitian terdahulu menunjukkan bahwa kangkung air (ipomoea aquatica) memiliki aktivitas antihiperglikemia pada tikus wistar yang di Induksi steptozotocin (STZ) (Malalavidhane et al., 2000; Malalavidhane et al., 2001; Malalavidhane et al., 2003). Kandungan dari kangkung air adalah $\beta$-karoten, riboflavin, Vitamin $C$, besi, dan kangkung air diyakini memiliki aktivitas antioksidan (Prasad et al., 2008; Dasgupta, 2006). Kangkung darat mengandung flavonoid, polyphenol, dan vitamin $\mathrm{C}$ dalam jumlah yang cukup tinggi, sehingga menghasilkan aktivitas antioksidan yang sangat tinggi dibandingkan dengan Centella asiatica, Nyctanthes arbortristis (Kalita ot al., 2006).

Publikasi ilmiah di dalam dan luar negeri yang mendukung data ilmiah kangkung darat (lpomoea reptans Poir) masih sangat minim. Oleh karenanya perlu dilakukan penelitian untuk mendukung data ilmiah kangkung darat (Ipomoea reptans Poir) sebagai salah satu obat alternative mengatasi DM. Melalui penelitian ini dikaji efek antihiperglikemia kangkung darat (Ipomoea reptans Poir) terhadap kadar glukosa mencit jantan yang diinduksi STZ.

\section{METODE PENELITIAN}

Alat-alat yang digunakan dalam penelitian ini adalah neraca analitik (Mettler Toledo), alatalat gelas, timbangan tikus (Ohauss), Gluko-Dr, strip glikotest, spatula. Bahan penelitian ini adalah subjek uji mencit puth jantan galur Swiss dengan berat badan $20-30$ gram berjumlah 36 ekor mencit yang diberi pakan tikus 1 kali sehari dan minum ad libitum. Hewan uji diperoleh dari Laboratorium Penelitian dan Pengujian Terpadu UGM, Yogyakarta. Bahan-bahan lain yang dipergunakan dalam penelitian ini adalah infusa kangkung darat (Ipomoea reptans Poir) yang 
diperoleh dari Pasar Pakem $\mathrm{km}$ 21, aquades dan buffer Na-Sitrat pH 4,5, metformin, dan STZ serbuk yang diperoleh dari CV. Kristalindo Biolab Surabaya.

Penelitian ini telah mendapatkan pengakuan kelayakan etika penelitian (ethical clearance) dari Komisi Etika Penelitian Bidang Kedokteran dan Kesehatan, Fakultas kedokteran UGM. Hewan coba terlebih dahulu diadaptasikan selama seminggu di laboratorium sebelum diberi perlakuan.

\section{Pembuatan infusa kangkung darat}

Kangkung darat (Ipomea reptans P) disortasi dan dicuci dengan air mengalir untuk menghilangkan kotoran yang menempel pada daun kangkung darat. Bahan yang digunakan dalam penelitian ini adalah batang dan daunnya saja, dengan dikeringkan di lemari pengering dan kemudian dipotong kecil-kecil. Sediaan infusa kangkung darat dibuat berdasarkan Farmakope Indonesia edisi ke-4 (Anonim, 1995). Pada penelitian ini dibuat infusa kangkung darat pada dosis yang sudah ditentukan oleh peneliti.

\section{Pengamatan efek hiperglikemia}

Penelitian dibagi menjadi dua tahapan, yaitu tahap seleksi dan tahap pemberian perlakuan.

1. Seleksi mencit berdasar kriteria inklusi dan eksklusi untuk dijadikan subyek uji penelitian Mencit dikatakanhiperglikemia ketika kadar gula darah mencit lebih dari $200 \mathrm{mg} / \mathrm{dl}$. Saat tahapan seleksi, mencit hanya dibagi dua kelompok, yaitu kelompok kontrol normal ( $n=5$ ekor) dan kelompok induksi STZ ( $n=30$ ekor). Kelompok kontrol normal tidak mendapatkan perlakuan apapun, dan kelompok induksi STZ, diberikan STZ untuk menginduksi hiperglikemia. Pada hari ke-0 mencit diukur terlebih dahulu kadar glukosa darah puasa sebagai baseline. Untuk menjadikan mencithiperglikemia, sebanyak 30 mencit pada hari ke-1 sampai hari ke-5 diinduksi STZ dosis tunggal $40 \mathrm{mg} / \mathrm{KgBB}$ secara intraperitonial yang telah dilarutkan di buffer $\mathrm{Na}$-Sitrat $\mathrm{pH} \mathrm{4,5}$, kemudian ditunggu efek hiperglikemia pada mencit sampai hari ke-13. Pada hari ke-13, dipisahkan antara mencit yang memenuhi kriteria hiperglikemia dan yang tidak memenuhi (Hidgon, 2004). Dipilih 25 mencit yang memenuhi syarat hiperglikemia dibagi secara acak dalam lima kelompok dan dipuasakan 8 jam sebelum diberikan perlakuan. Kemampuan STZ dalam menginduksi dinyatakan dalam parameter persentase kenaikan KGDP.

2. Uji efek antihiperglikemia ekstrak kangkung darat pada mencit yang diinduksi streptozotosin dengan parameter kadar glukosa darah puasa (KGDP)

Rancangan penelitian yang digunakan adalah pretest posttest control group design, dengan pengelompokan hewan coba secarara acak lengkap. Penelitian menggunakan 30 mencit yang dibagi menjadi 6 kelompok, yaitu kelompok I sebagai kelompok kontrol normal, yang mana mencit hanya diberikan makan dan minum seperti biasa, kelompok II sebagai kelompok kontrol negatif, yang mana mencit hanya dilnduksi streptozotocin 5 hari berturut-turut dosis $40 \mathrm{mg} / \mathrm{KgBB}$ secara intraperitonial, kelompok III sebagai kelompok kontrol positif, yang mana mencit diinduksi streptozotocin 5 hari berturut-turut dosis $40 \mathrm{mg} / \mathrm{KgBB}$ secara intraperitonial, setelah hari ke-13 diberikan metformin $3,9 \mathrm{mg} / 20 \mathrm{~g}$ BB secara per oral (berdasarkan konversi dosis pada manusia), kelompok IV sebagai kelompok perlakuan I yang mana mencit diinduksi 
streptozotocin 5 harl berturut-turut dosis $40 \mathrm{mg} / \mathrm{KgBB}$ secara intraperitonial, setelah hari ke 13 diberikan infusa kangkung dosis 44,64 mg/20 gB8, keiompok V sebagai kelompok perlakuan II yang mans mencit dinduksi streptozotocin 5 hari bertunt-turut dosts $40 \mathrm{mg} / \mathrm{KgBB}$ secara intraperitonial, setelah hari ke-13 diberikan infusa kangkung dosis $89,28 \mathrm{mg} 20 \mathrm{gBB}, \mathrm{kalompok}$ VI sebagai keiompok pertakuan III yang mana mencit diinduksi streptozotocin 5 hari berturutturut dosis $40 \mathrm{mg} / \mathrm{KgBB}$ secara Intraperitonial, setelah hari ke-13 diberikan infusa kangkung dosis 178,56 mg/20gBB. Mencit dimonitoring setiap hari dan di timbang berat badan setiap hari. Penetapan KGDP dengan Glukotest dilakukan pada hari ke-0, hari ke-13, dan hari ke-20. Komampuan monurunkan KGDP dinyatakan dalam parameter perscrtase penununan KGDP.

$$
\begin{gathered}
\text { Persentase Kentikan KGDP }=\frac{\text { KGDP DM(hari ke-13) }- \text { KGDP awal (hari ke-0) }}{\text { KGDP DM (hari ke-0) }} \\
\text { Persentase Penurunan KGDP }=\frac{\text { KGDP DM(hari ke-13) }- \text { KGDP awal (thari ke-20) }}{\text { KGDP DM (hari ke-13) }}
\end{gathered}
$$

Hasil pengukuran KGDP yang diperoleh dianalisis secara statlstik $(p=0,05)$ dengan monggunakan Analysis of Covariance atau Analisis kovarian untuk mongetahui perbedaan KGDP harl-20, harl ke-13, dan harl ke-0 pada variasi dosis.

\section{HASIL DAN PEMBAHASAN}

Pada penelitian ini mencit dinduksi hiperglikemia dengan menggunakan STZ (Lenzen, 2008). Mencit yang telah dilinduksi dengan STZ dosis $40 \mathrm{mg} / \mathrm{kgBB} 5$ harl berturut-turut (Wu and Huan, 2008) diukur kadar glukosa puasanya dan komudian diseleksi torlobih dahulu. Moncit yang memenuhl krtterla inklusi dengan kadar glukosa darah > 200mg/di (Tian at al., 2010) kemudlan dikelompokkan sebagai kelompok perlakuan.

Tabel 1. Pengaruh kadar glukosa darah rata-rata sebelum induksi STZ dan sesudah induksi STZ dosis $40 \mathrm{mg} / \mathrm{kgBB}$ pada mencit Bwiss jantan pada harl-13

\begin{tabular}{lcc}
\hline \multirow{2}{*}{ Kelompok } & \multicolumn{2}{c}{ Kadar Glukasa Darah(mojd) } \\
\cline { 2 - 3 } & Sebelum Induksi STZ & Sesudah Induksi STZ \\
& $(\mathrm{X} \pm \mathrm{SD})$ & $(\mathrm{X} \pm \mathrm{SD})$ \\
\hline Nomal $(\mathrm{N}=5)$ & $100,2 \pm 11,4$ & $125,2 \pm 11,8$ \\
Induksi STZ $(\mathrm{N}=25)$ & $96,8 \pm 22,6$ & $320 \pm 78,6$ \\
\hline
\end{tabular}




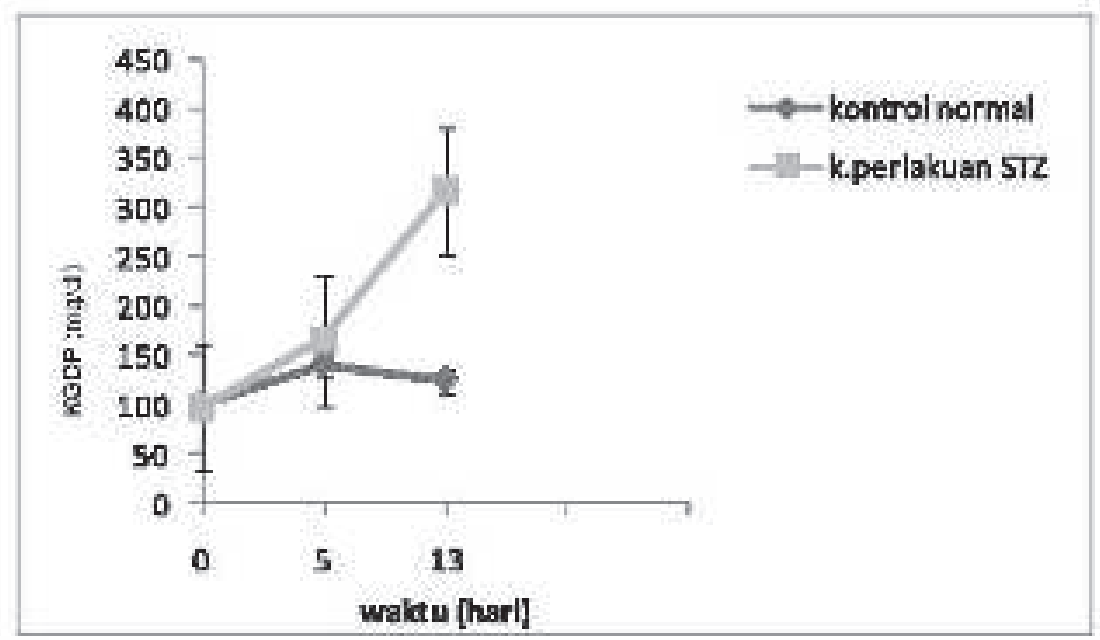

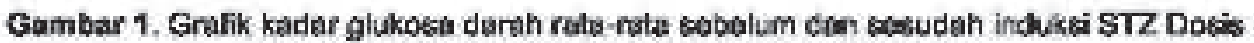
$40 \mathrm{mg} / \mathrm{kgBB}$ secara $1 . P$ aglama 5 hari berturut-turut

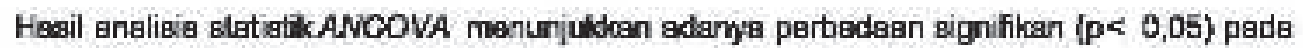
pengukuran har ke-13 (dangan mampertitungkan pengukuran pada har ko-0), sthingga memperkugt kesimpulen balmwa menclt ksiampck perkikuen takh mengaleml hlperglikemla. Konaikan kadar glukose darah pada kolompak periakan ratarkta sobochir 262,01\% jauh ofitas kanalkan kadar qlukosg darah kekmpok norrnal sebegar $25.35 \%$.

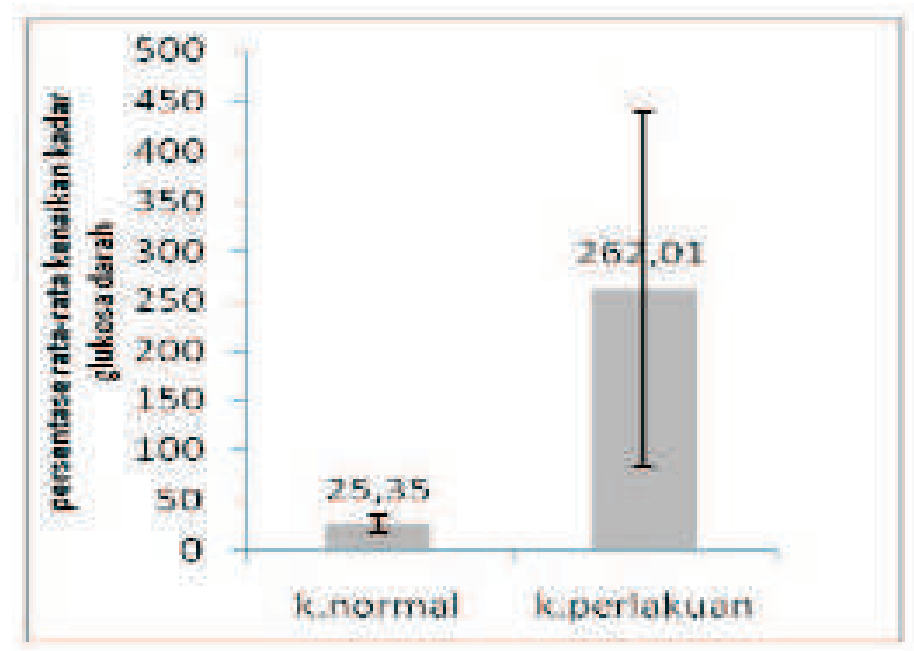

Gambar 2. Bagan persentase rata-raka kenalkan kadar glukosa darah puaga pada harl ke-13 totolah diinduksi STZ dotis $40 \mathrm{mg} / \mathrm{kg}$ b

Mencit yang telah mengalamihiperglikemia dibagi dalam 5 kalompok secara acak, menjadi kelompok kontrol negalif, kontrol posilif, dan 3 kadompok doeie pertakuan infusa kangkung darat. Mencit mandapatkan periakuaninfusa kangkung darat hari ke 13-18, peda hari ke-20 dilakuken penqukuran kadar qukos:a darah. 
Tabel 2. Kadar glukosa darah puasa rata-rata mencit setelah diberi perlakuan pada harl ke 13-19

\begin{tabular}{llll}
\hline \multicolumn{1}{c}{$\begin{array}{c}\text { Kolompok Perlakuan } \\
(\mathrm{N}=5)\end{array}$} & \multicolumn{3}{c}{ Kadar Clukosa Darah Pussa (rata-rata \pm SD) } \\
\cline { 2 - 4 } & \multicolumn{1}{c}{ Hari-0 } & \multicolumn{1}{c}{ Hari-13 } & \multicolumn{1}{c}{ Hari-20 } \\
\hline kontrol nommal & $100,2 \pm 11,4$ & $125,2 \pm 11,8$ & $138,8 \pm 17,9$ \\
kontrol positf & $130,4 \pm 22,6$ & $219 \pm 25,7$ & $152,4 \pm 12,3$ \\
kontrol negatif & $113,4 \pm 11,9$ & $245,8 \pm 35,9$ & $354 \pm 69,8$ \\
infusa kangkuing darat 44,64mg/20gB8 & $77,8 \pm 9,2$ & $426,8 \pm 97,4$ & $354,6 \pm 230,2$ \\
infusa kangkung darat $89,28 \mathrm{mg} / 20 \mathrm{gBB}$ & $78,8 \pm 3,8$ & $342 \pm 119,4$ & $237,2 \pm 175,3$ \\
infusa kangkung darat $178,56 \mathrm{mg} / 20 \mathrm{gBB}$ & $86,2 \pm 40,4$ & $349,2 \pm 134,2$ & $285,8 \pm 137,5$ \\
\hline
\end{tabular}

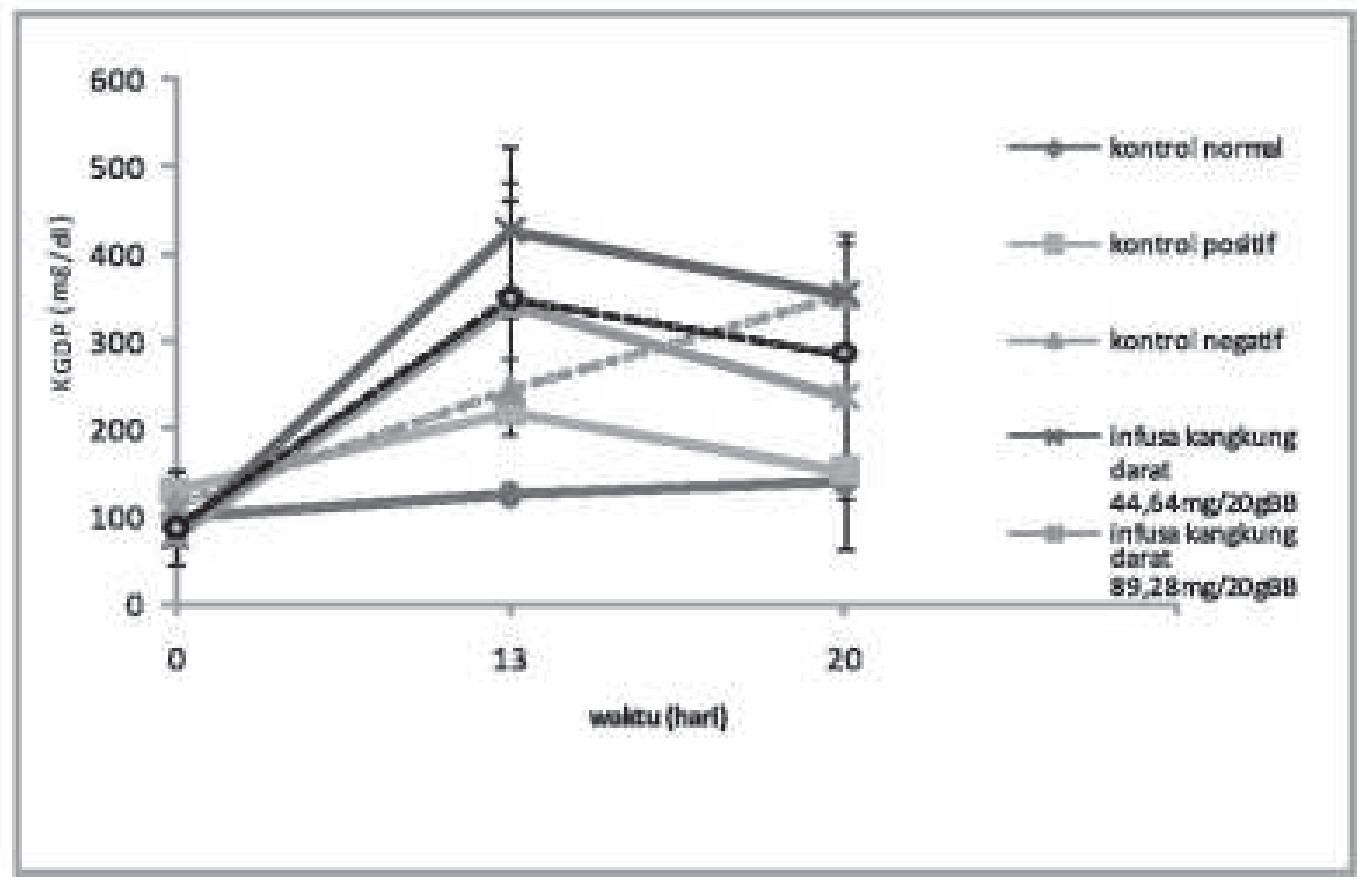

Gambar 3. Grafik kadar glukosa darah puasa rata-rata mencit Swss jantan setolah diber perlakuan

Hasil analisls statistk ANCOVA menunjukkan adanya perbedaan signifikan $(p<0,05)$ nilal kadar glukesa darah mencit antar kelompok kontrol negatif dengan kelompok kontrol posilif, kelompck infusa kangkung darat dosis $44,64 \mathrm{mg} / 20 \mathrm{gBB}, 89,28 \mathrm{mg} / 20 \mathrm{~g} \mathrm{BB}$, dan $178,56 \mathrm{mg} / 20 \mathrm{~g} \mathrm{BB}$ pada pengukuran hari ke-20 dengan memperhatkan nilai kadar glukosa darah pada hari ke-13. Hal itu menunjukkan adanya efek penurunan kadar glukosa darah mencit pada kalornpok kontrol positf dan kelompok yang diberi infus kangkung darat. Porsentase rata-rata penurunan kadar glukosa darah meneit berturut-turut dari yang tertinggi ditunjukkan oieh kelampok periakuan infusa kangkung darat dosis $89,29 \mathrm{mg} / 20 \mathrm{gBB}(34,44 \%)$, kelompok perlakuan infusa kangkung darat dosis $178,56 \mathrm{mg} / 20 \mathrm{ga \theta}(31,18 \%)$, kelompok kontrol positt $(29,66 \%)$, kelompok periakuan Infusa kangkung darat dosis 44,64 my/20gB8 $(21,27 \%)$. 


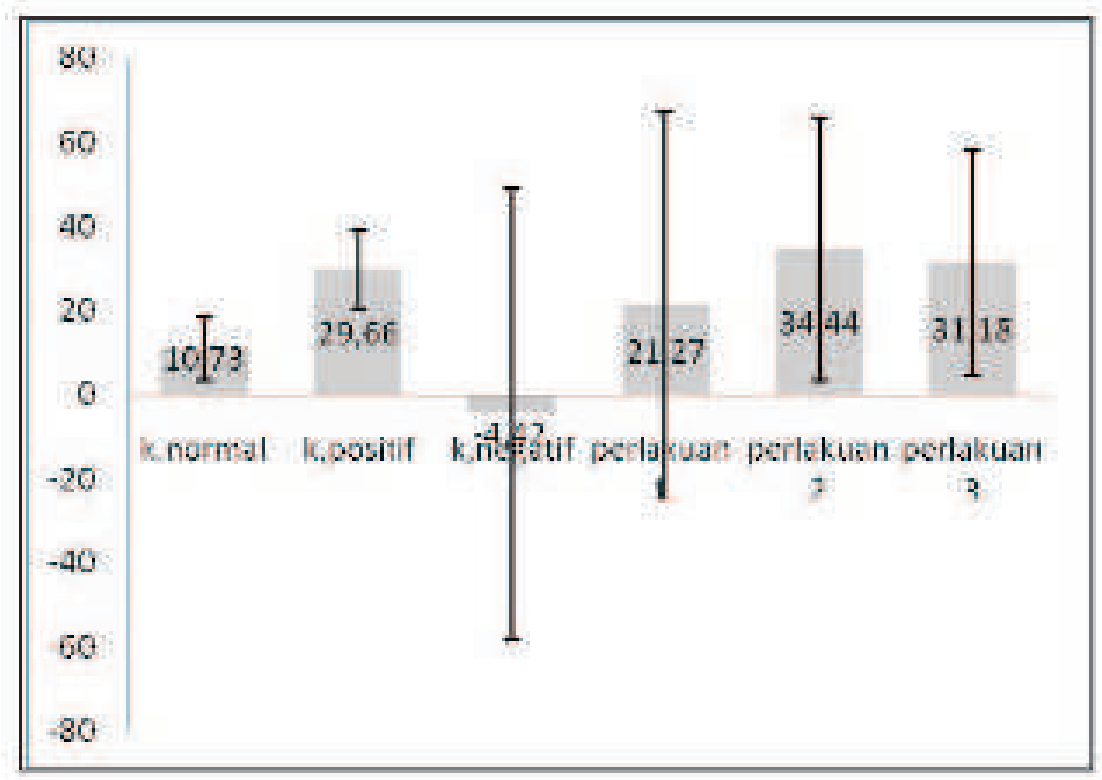

Gambar 4. Pareantage penurunan KCDP hari ka-20 aetelah diberi pertakuan infusa kangkung derat dosis 44,64mg/20,gBB; $89,2 \mathrm{Bmg} 20 \mathrm{gBB} ; 178,56 \mathrm{mg} / 20 \mathrm{gBB}$

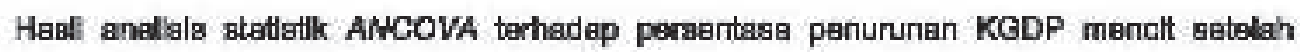
pamianian intusa kangkung darat memunjulkan perbadaan yang signinkan $(p<0,05)$. Terdapat perbedaen nyate antara kontrol negatif dengan kontrol posituf den seluruh kelcmpok dosis

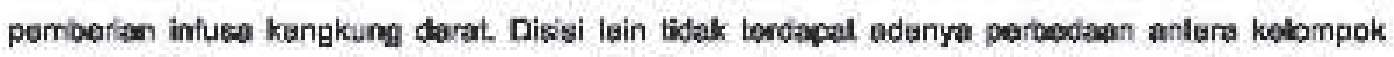
kontral positif dengan seluruh kslompok dosis infusa kangkung daral. Hal inimenunjukkan balmwa seturh kelompok dosis infusa kangkung darat memberikan efek anthiperglikemia tidak berbeda nilainya dengan elak yang dimilki obeh matiormin.

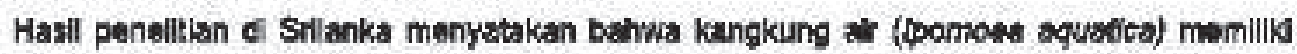
aktlvitas anthlpergllkernla (Malalewldhane ot al, 2001). Sabagalmana kangkung alr, karikung

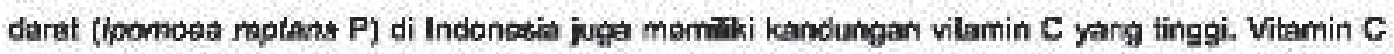
merupakan Buatu anilaksiden yang dapal mellindungl molekul-molekul yang diperluken cleh tubuh, soporti protuin, lipid, karbohidrat, dan asam nwiclogt dari korusakan radikal bebes dan ronktif oksigen spesies (Wuend Husn, 2008) Vitamin C dbutuhkan untuk mengurangi resiko terjadinya DM (Sardi, 2004).

Indukes DMA pada mencet Swies janten dilakukan dengan cara menginduksi ST2 yang audah dllarutkan kedalam buffer na-sltrat pH 4,5. Nekanisme STZ dalam mengine

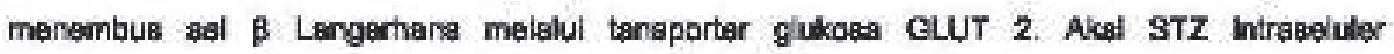
menghragikan perubehan DNA sel $\beta$ pankraes. Alkilesi DNA oieh STZ melalui gugues nitrosourea mengaklbatkan kerugakan pada sel B pankrsas STZ menupakan donor NO yang mempunyal kontribusi terhadap kenusakan sel trractut melalui peningkgtan aldivites guanil stase den pembentukan cGMP. NO dihasillkan sewraktu STZ mengalami metabolisme dalam sel. Setain tu, STZ luge mampu membangkötkan oksigan reaktï yeng mempunyai peran tinggi dalam kerusakan sel a paniaras. Pambentukan ankon superoksids karena aksi STZ dslam mitokondria can 
peningkatan aktivitas xantin oksidase. Dalam hal ini, STZ menghambat siklus krebs dan menurunkan konsumsi oksigen mitokondria. Produksi ATP mitokondria yang terbatas selanjutnya mengakibatkan pengurangan secara drastis nukleotida sel $\beta$ pankreas (Lenzen, 2008);

Antioksidan merupakan senyawa yang dapat melindungi sel terhadap ROS. Tingginya radikal bebas dan menurunnya kekebalan antioksidan akan menyebabkan kerusakan organella sel dan enzim, peningkatan lipid peroksida, dan resistensi insulin (Maritim et al., 2002). Pemberian antioksidan berupa vitamin dapat mengurangi stres oksidatif bagi penderita DM baik kronis maupun akut. Hasil penelitian di Turki menunjukkan pada tiga puluh penderita DM tipe 2 ditemukan adanya ketidakseimbangan oksidan dan antioksidan dalam plasma penderita DM dibanding kontrol. Pemberian vitamin $\mathrm{C}$ dosis tinggi $2 \mathrm{~g}$ /hari dapat memperbaiki kesehatan penderita DM untuk meminimalkan terjadinya komplikasi makrovaskular dan komplikasi mikrovaskular (Widowati, 2008).

Sumber stres oksidasi pada DM diantaranya perpindahan keseimbangan reaksi redoks karena perubahan metabolisme karbohidrat dan lipid yang akan meningkatkan pembentukan ROS dari reaksi glikasi dan oksidasi lipid sehingga menurunkan sistem pertahanan antioksidan diantaranya Glutation. Penurunan glutation ini menyebabkan resistensi insulin dan terjadilah DM (Halliwel and Gutteridge, 1999). Stres oksidatif pada penderita DM akan meningkatkan pembentukan ROS di dalam mitokondria yang akan mengakibatkan berbagai kerusakan oksidatif berupa komplikasi DM dan akan memperparah kondisi penderita diabetes, untuk itu perlu menormalkan kadar ROS di mitokondria untuk mencegah kerusakan oksidatif (Widowati, 2008).

Kangkung darat (Ipomoea reptans Poir.) merupakan sayuran yang banyak ditemukan di Indonesia. Kandungan dari kangkung darat adalah flavonoid, polyphenol. Kangkung darat (lpomoea reptans Poir. ) memiliki aktivitas antioksidan yang sangat tinggi didalamnya dibandingkan dengan Centella asiatica, Nyctanthes arbortristis (Dasgupta, 2006). Penelitian yang berbeda menyatakan bahwa kangkung darat (Ipomoea reptans $\mathrm{P}$ ) memilki jumlah vitamin $\mathrm{C}$ paling tinggi dibandingkan dengan Salvinia cuculata, Trapa natans, Lemna minor (Kalita өt al., 2006). Penelitian antihiperglikemia pada bahan alam yang lain, menyebutkan bahwa antioksidant pada Pyllanthus meedi memiliki efek antihiperglikemia pada tikus yang diinduksi STZ (Sivajothi et al, 2008). Hal ini semakin mendukung kemungkinan bahwa antioksidan pada kangkung darat (ipomoea reptans P) juga memiliki efek antihiperglikemia.

Mekanisme kangkung darat sebagai antihiperglikemia dengan cara mencegah komplikasi DM tipe 2 dengan penghambatan produksi sorbitol. Sorbitol adalah hasil samping dari metabolism glukosa yang akandiakumulasikan di dalam sel dan berperan terhadap perkembangan neuropati dan katarak, meminimalkan pembentukan AGEs (Advanced Glycogen end Product) sehingga proses glikasi non enzimatik dapat dicegah. Selain itu, juga menghambat masuknya glukosa melalui GLUT transporter kedalam sel sehingga mengurangi gangguan vasodilatasi tergantung sel endotel (Widowati, 2008; Setiawan dan Suhartono, 2005).

Pada penelitian yang dilakukan oleh Malalavidhane, kangkung air memiliki efek antihiperglikemia pada tikus galur Wistar yang diinduksi STZ pada dosis $130 \mathrm{mg} / 200 \mathrm{gBB}$ perhari (Malalavidhane et al., 2003). Sedangkan pada penelitian ini kangkung darat (lpomoea reptans P) menunjukkan efek antihiperglikemia pada mencit Swiss jantan dosis $44,64 \mathrm{mg} / 20 \mathrm{gBB}$; 

Lenzen, 2008, The mechanism of alloxan and STZ induced diabetes, Diabetologia, 51, 216-226

Malalavidhane, T.S., Wickramasinghe S.M., and Jansz, E.R., 2000, Oral hypoglycemic activity of Ipomoea aquatic, J. Ethnopharmacol. 72, 293-298

Malalavidhane, T.S., Wickramasinghe, S.M., and Jansz,E.R., 2001,. An aqueous extract of the green leafy vegetable Ipomoea aquatica is as effective as the oral hypoglycemic drug tolbutamide in reducing the blood sugar levels of Wistar rats, Phytother, 15, 635-637

Malalavidhane, T.S., Wickramasinghe, S.M.D.N., Perera, M. S.A., Jansz, E.R., 2003, Oral hypoglycaemic activity of lpomoea aquatic in STZ induced, diabetic Wistar rats and type II diabetics, Phytother, Vol.17, 1098-1100

Maritim, A.C., Sanders, A.R., Watkins B.J., 2002, Diabetes, oxidative stress, and antioxidants: a review, J Biochem Molecular Toxycology, 17, 24

Prasad, K.N., Shivamurthy, G.R., Aradhya, M.S., 2008, Ipomoea aquatica, an underutilized green leafy vegetable: a review, International Joumal of Botany, 4 (1), 123-129

Sardi, B., 2004, Premature Birt, Life Long Development Problems Linked to Low Vitamin C Levels During Pregnancy, Knowledge of Health, Inc

Setiawan, B., Suhartono, E., 2005, Stress oxidatif \& peran antioksidan pada diabetes mellitus, Majalah Kedokteran Indonesia, Vol.55, 2

Sivajothi, V., Dey, A., Jayakar, B., and Rajkapoor, B., 2008, Antihyperlycemic, antihyperlipidemic and antioxidant effect of Phyllanthus reheөdii on STZ induced diabetic rats, Iranian Journal Of Pharmaceutical Research, Vol.7, 53-59

Suyono S, Sudoyo AW, Setiyohadi B, Alwi I, Simadibrata M, Setiati S, 2007, Diabetes Mellitus di Indonesia. dalam buku ajar ilmu penyakit dalam, Jilid III, Edisi IV, Pusat Penerbitan Departemen IImu Penyakit FKUI, Jakarta, 1852 - 6

Tian,H.L., Wei, L.S., Gao, J.S., Xu, Z.X., Zhao, R.T, Jing, D.L., 2010, Correlations between blood Glucose level and diabetic signs in STZ induced diabetic mice, Global J.Pharmacology, 4 , $111-116$

Widowati, W., 2008, Potensi Antioxidant sebagai antidiabetes, Laporan Penelitian dan Pengembangan IImu Kedokteran Dasar (LP2IKD), Fakultas Kedokteran, Universitas Kristen Maranatha, Bandung

Wu, K.K., Huan, Y., 2008, STZ Induced diabetic models in mice and rats, Current Protocol in Pharmacology, 40, 5.47.1 - 5.47.14 